\title{
PENGARUH KETERLIBATAN KERJA DAN PENGALAMAN KERJA TERHADAP KOMITMEN ORGANISASI PEGAWAI DI DINAS PENDIDIKAN KABUPATEN BEKASI
}

\author{
Andri Cahyo Purnomo ${ }^{1}$ \\ Po. Abas Sunarya ${ }^{2}$ \\ Rise Wijoyo Jati ${ }^{3}$ \\ Dosen STMIK Raharja ${ }^{1}$, Dosen AMIK Raharja Informatika ${ }^{2}$, STMIK Raharja Jurusan Sistem \\ Informasi $^{3}$ \\ Jl. Jendral Sudirman No. 40, Modern Cikokol, Tangerang \\ Email : andricahyo@ raharja.info ${ }^{1)}$, abas@raharja.info ${ }^{2)}$, rise@ raharja.info $^{3)}$
}

\begin{abstract}
ABSTRAK
Komitmen organisasi merupakan keterikatan seseorang pada organisasi. Pegawai yang berkomitmen terhadap organisasi akan memiliki keinginan yang kuat untuk menjadi anggota organisasi, keinginan untuk berusaha keras sesuai keinginan organisasi, dan memiliki kepercayaan dan penerimaan terhadap nilai dan tujuan organisasi. Organisasi akan semakin efektif jika pegawainya memiliki komitmen yang tinggi. Penelitian ini bertujuan untuk mengetahui pengaruh (1) keterlibatan pekerjaan, (2) pengalaman kerja, (3) komitmen organisasi di Dinas Pendidikan Kabupaten Bekasi. Dalam analisis data, penelitian ini menggunakan metode survei kausal dengan menggunakan Path Analysis Technique. Penelitian ini menggunakan sampel dari 97 pegawai di Dinas Pendidikan Kabupaten Bekasi yang dipilih dengan menggunakan rumus Slovin. Hasil penelitian mengungkapkan bahwa: pertama, keterlibatan kerja berpengaruh langsung positif terhadap komitmen organisasi. Artinya peningkatan keterlibatan kerja mengakibatkan peningkatan komitmen organisasi pegawai di Sekretariat Badan Pengembangan Sumber Daya Manusia Kementerian Perhubungan RI. Kedua, pengalaman kerja berpengaruh langsung positif terhadap komitmen organisasi. Artinya peningkatan pengalaman kerja mengakibatkan peningkatan komitmen organisasi pegawai di Sekretariat Badan Pengembangan Sumber Daya Manusia Kementerian Perhubungan RI. Ketiga, Keterlibatan kerja berpengaruh langsung positif terhadap pengalaman kerja. Artinya peningkatan keterlibatan kerja mengakibatkan peningkatan pengalaman kerja pada pegawai di Sekretariat Badan Pengembangan Sumber Daya Manusia Kementerian Perhubungan RI. Dari hasil penelitian juga didapatkan bahwa variabel yang paling berpengaruh adalah keterlibatan kerja terhadap komitmen organisasi, hal ini dapat dibuktikan dari hasil perhitungan statistik dengan nilai $r 13=0,426, p 32=0,328$ paling tinggi dibandingkan pengaruh antar variabel lainnya. Tindak lanjut dari penelitian ini, pegawai diharapkan memiliki keterlibatan kerja yang tinggi serta sikap kecintaan terhadap pekerjaannya sehingga pegawai akan lebih ikhlas dan tulus dalam melakukan pekerjaannya selain itu pegawai juga akan memiliki rasa tanggung jawab yang besar dan rasa kepemilikan terhadap organisasi dan keseluruhannya tersebut yang akan membawa keinginan pegawai untuk melakukan pekerjaan melebihi apa yang diharapkan, melakukan pekerjaan dengan optimal serta memaksimalkan dirinya agar dapat lebih berguna bagi organisasi.
\end{abstract}

Kata kunci: keterlibatan pekerjaan, pengalaman kerja dan komitmen organisasi 


\begin{abstract}
Organizational commitment is a person's attachment to the organization. Employees who are committed to the organization will have a strong desire to become members of the organization, the desire to strive according to the wishes of the organization, and have the trust and acceptance of the values and goals of the organization. Organizations will be more effective if their employees have a high commitment. This study aims to determine the effect of (1) job involvement, (2) work experience, (3) organizational commitment in the Bekasi District Education Office. In data analysis, this study uses causal survey method using Path Analysis Technique. This study used a sample of 97 employees in the Bekasi District Education Office who were selected using the Slovin formula. The results reveal that: first, work involvement has a direct positive effect on organizational commitment. This means that the increase in work involvement has resulted in an increase in the commitment of employee organizations at the Secretariat of the Human Resources Development Agency of the Ministry of Transportation of the Republic of Indonesia. Second, work experience has a direct positive effect on organizational commitment. This means that an increase in work experience has resulted in an increase in the commitment of employee organizations at the Secretariat of the Human Resources Development Agency of the Ministry of Transportation of the Republic of Indonesia. Third, work involvement has a direct positive effect on work experience. This means that the increase in work involvement has resulted in an increase in work experience for employees at the Ministry of Transportation's Human Resources Development Agency Secretariat. From the results of the study also found that the most influential variables are work involvement on organizational commitment, this can be proven from the results of statistical calculations with a value of $r 13=0.426, p 32=0.328$ the highest compared to the influence of other variables. Follow-up of this study, employees are expected to have high work involvement and attitude of love for their work so that employees will be more sincere and sincere in doing their work. In addition, employees will also have a great sense of responsibility and a sense of ownership of the organization and the whole that will bring the desire of employees to do work beyond what is expected, to do work optimally and maximize themselves to be more useful for the organization.
\end{abstract}

Keywords : job involvement, work experience and organizational commitment

\title{
PENDAHULUAN
}

Sumber Daya Manusia (SDM) merupakan sumber daya organisasi vital dan sentral di masa yang akan datang. SDM senantiasa melekat pada setiap sumber daya organisasi apapun sebagai faktor penentu keberadaan dan peranannya dalam memberikan kontribusi ke arah pencapaian tujuan organisasi secara efektif dan efisien. Salah satu aspek penting aspirasi setiap SDM adalah berkaitan dengan aspirasi dan sikap terhadap pekerjaan.

Faktor pekerjaan ini dapat menjadi indikator ketepatan aspirasi sikap personil suatu organisasi sebagai imbas berbagai pendekatan kebijaksanaan organisasional. Keberhasilan dan kinerja seseorang dalam suatu bidang pekerjaan banyak ditentukan oleh tingkat kompetensi, profesionalisme juga komitmen terhadap bidang yang ditekuninya.

Suatu komitmen organisasi menunjukkan suatu daya dari seseorang dalam mengidentifikasikan keterlibatan dalam suatu organisasi. Oleh karena itu komitmen organisasi akan menimbulkan rasa ikut memiliki (sense of belonging) bagi pekerja terhadap organisasi. Terjadinya perubahan-perubahan dalam organisasi juga mempunyai dampak pada terjadinya perubahan dalam tugas dan kewajiban pegawai. Organisasi merupakan perangkat sosial dan teknologi yang terdiri dari faktor-faktor manusia dan fisik. Dibantu oleh penerapan teknologi, manusia melakukan fungsi atau tugas yang menuntun kepada tercapainya sasaran yang ditentukan secara rasional. Manusia di dalam suatu organisasi dipandang 
sebagai sumber daya, artinya sumber daya atau penggerak dari suatu organisasi. Roda organisasi sangat tergantung pada perilaku-perilaku manusia yang bekerja di dalamnya.

Komitmen organisasi merupakan keterikatan seseorang pada organisasi. Pegawai yang berkomitmen terhadap organisasi akan memiliki keinginan yang kuat untuk menjadi anggota organisasi, keinginan untuk berusaha keras sesuai keinginan organisasi, dan memiliki kepercayaan dan penerimaan terhadap nilai dan tujuan organisasi. Organisasi akan semakin efektif jika pegawainya memiliki komitmen yang tinggi. Pegawai yang memiliki komitmen tinggi akan berdampak pada: (1) Pegawai itu sendiri, misalnya terhadap perkembangan karir pegawai dalam organisasi. (2) Organisasi. Pegawai yang berkomitmen tinggi pada organisasi akan menimbulkan kinerja yang tinggi, tingkat absensi berkurang, loyalitas pegawai dan lainlain. Dengan melihat hal tersebut setiap organisasi berusaha untuk membangun dan meningkatkan komitmen organisasi dari para pegawainya.

Berdasarkan informasi yang diperoleh dari Kepala Dinas Pendidikan Kabupaten Bekasi, ditemukan bahwa rendahnya komitmen organisasi pegawai disebabkan karena beberapa hal diantaranya: (1) alasan pegawai yang sering dilibatkan dalam pekerjaan tambahan diluar jam dinas hanya beberapa orang saja, dikarenakan pengalaman kerja yang lebih baik, (2) pegawai yang jarang terlibat dalam pekerjaan di luar jam dinas pengalamannya masih minim dan harus banyak belajar, (3) tampak bahwa pegawai yang sering terlibat menunjukan komitmen yang tinggi dari pada pegawai yang jarang dilibatkan, (4) rendahnya tingkat kedisiplinan dan loyalitas pegawai yang berimplikasi langsung kepada pencapaian tujuan organisasi, pegawai yang sering dilibatkan memiliki kedisiplinan jam kerja yang lebih tinggi. (Hasil informasi yang diperoleh dari Kepala Dinas Pendidikan Kabupaten Bekasi, 17 Januari 2016). ${ }^{[1]}$

Berdasarkan kondisi tersebut di atas maka dapat dikatakan bahwa rendahnya komitmen organisasi pegawai mencerminkan kurangnya tanggung jawab seseorang dalam menjalankan tugasnya. Dari beberapa faktor yang mempengaruhi komitmen organisasi pegawai, dibatasi hanya pada pengaruh keterlibatan kerja dan pengalaman kerja terhadap komitmen organisasi pegawai di Dinas Pendidikan Kabupaten Bekasi.

\section{Pembatasan Masalah}

Berdasarkan identifikasi masalah tersebut di atas maka peneliti hanya membatasi masalah penelitian pada pengaruh keterlibatan kerja dan pengalaman kerja terhadap komitmen organisasi.

\section{Rumusan Masalah}

Berdasarkan uraian dalam latarbelakang dan pembatasan masalah tersebut di atas, maka rumusan masalah dalam penelitian ini adalah sebagai berikut:

1. Apakah terdapat pengaruh langsung keterlibatan kerja terhadap komitmen organisasi?

2. Apakah terdapat pengaruh langsung pengalaman kerja terhadap komitmen organisasi?

3. Apakah terdapat pengaruh langsung keterlibatan kerja terhadap pengalaman kerja?

\section{Komitmen Organisasi}

Komitmen organisasi merupakan unsur penting yang harus dimiliki oleh tiap anggota dalam setiap organisasi jika menginkan organisasi yang maju dan berkelanjutan. Tanpa adanya komitmen dalam diri tiap anggota di organisasinya, maka organisasi tersebut 
dipastikan tidak akan berkembang sesuai dengan apa yang sudah direncanakan bahkan cenderung mengalami kemunduran.

Menurut Colquitt LePine dan Wesson (2009:69), mengemukakan bahwa,"organizational commitment is define as the desire on the part of an employee to remind a member of organization". ${ }^{8]}$ Komitmen organisasi didefinisikan sebagai upaya untuk mengingatkan pegawai merupakan bagian dari organisasi. Sementara itu Stephen P. Robbins and Timothy A. Judge (2007:74), mengatakan bahwa, "organizational is defined as a state in the which an employee identifies with a particular organization and its goal and wishes to maintain membership in the organization". ${ }^{[20]}$ Komitmen organisasi didefinisikan sebagai keadaan di mana seorang pegawai mengidentifikasi dirinya dengan organisasi dan tujuannya serta berkeinginan untuk mempertahankan keanggotaannya dalam organisasi tersebut. Selanjutnya, menurut Armstrong and Taylor (2014:186), "organizational commitment is a multidimensional construct that reflects a workers: identification with the organization (loyalty), attachment to the organization (intention to stay), and willingness to expend effort on the organization's behalf (discretionary effort)"' ${ }^{[6]}$ Komitmen organisasi adalah membangun multidimensi yang mencerminkan pekerja: identifikasi dengan organisasi (loyalitas), lampiran untuk organisasi (niat untuk tinggal), dan kesediaan untuk mengeluarkan usaha atas nama (upaya diskresi) organisasi.

Menurut Stephen P. Robbins and Mary Coulter (2002:372), “organizational commitment represents and employee's orientation towards the organization in terms of his of her loyalty to, identification with, and involvement in the organization". "17] Komitmen organisasi merepresentasikan orientasi pegawai terhadap tujuan organisasi, loyal/setia dengan organisasi, dapat mengidentifikasi diri dengan organisasi dan terlibat dalam organisasi. Lebih lanjut Don Hellriegel and J. W. Slocum (2011:91), "organizational commitment is characterized by: a). support of and acceptance of the organization's goals and values, $b$ ). $a$ willingness to exert and considerable effort on behalf of the organizational and c). a desire to remain with the organization". ${ }^{[10]}$ Komitmen organisasi mengacu pada kekuatan keterlibatan pegawai dalam organisasi dan identifikasi komitmen organisasi yang kuat dicirikan oleh a). Dukungan dan penerimaan tujuan organisasi dan nilai-nilai, b). kemauan untuk mengerahkan usaha yang cukup atas nama organisasi dan c). keinginan untuk tetap dengan organisasi.

Berdasarkan uraian di atas, dapat disintesiskan bahwa komitmen organisasi merupakan ketetapan seseorang untuk mempertahankan keanggotaannya dalam sebuah organisasi, dengan indikator: (1) keyakinan diri, (2) keinginan untuk mempertahankan organisasi, (3) kesetiaan dalam pekerjaan, (4) adanya dukungan organisasi dan, (5) kebanggaan pegawai.

\section{Keterlibatan Kerja}

Menurut Schermerhorn et.al (2010:72) berpendapat bahwa, "job involvement is the extent to which an individual is dedicated to a job" ${ }^{[5]}$ Keterlibatan kerja adalah sejauh mana seorang individu didedikasikan untuk pekerjaan. Selanjutnya menurut Stephen P. Robbins, Mary Coulter (2012:377), "job involvement is the degree to which an employee identifies with his or her job, actively participates in it, and considers his or her job performance to be important to his or her self-worth."[18] Keterlibatan kerja adalah sejauh mana seorang karyawan diidentifikasikan dengan pekerjaannya, aktif berpartisipasi di dalamnya, dan menganggap prestasi kerjanya merupakan hal yang penting bagi dirinya. Sedangkan menurut Noe et. al. (2011:308) mengemukakan bahwa, "job involvement is the degree to which 
people identify themselves with their jobs. People with a high level of job involvement consider their work an important part of their life. "[ ${ }^{4]}$ Keterlibatan kerja adalah sejauh mana orang mengidentifikasi diri mereka dengan pekerjaan mereka. Orang-orang dengan tingkat keterlibatan kerja yang tinggi menganggap pekerjaan mereka merupakan bagian penting dari hidup mereka. Sedangkan menurut Aaron Cohen (2009:34), "job involvement is a belief about the current job and tends to be a function of how much the job can satisfy one's immediate needs". ${ }^{[3]}$ Keterlibatan kerja adalah keyakinan tentang pekerjaan saat ini dan cenderung menjadi fungsi dari seberapa banyak pekerjaan tersebut dapat memenuhi kebutuhan mendesak seseorang. John B. Miner (2009:143) mengatakan bahwa, "job involvement is considered a desirable opportunity for self expression for a sizable number of subjects". ${ }^{[7]}$ Keterlibatan kerja dianggap sebagai kesempatan yang diinginkan untuk mengekspresikan diri dari sebagian besar subyek. Selanjutnya menurut Robert Kreitner and Angelo Kinicki (2010:169) menyatakan bahwa, "job involvement is defined as the degree to which one is cognitively preoccupied with, engaged in, and concerned with one's present job. This work attitude manifests itself through the extent to which people are immersed in their job tasks". ${ }^{[21]}$ Keterlibatan kerja adalah sejauh mana seseorang pegawai disibukkan, terlibat, dan peduli dengan pekerjaannya. Sikap kerja ini memanifestasikan dirinya sejauh mana orang tenggelam dalam tugas-tugas pekerjaan mereka. Menurut John W. Newstrom and Keith Davis (2002:211) menyatakan, "job involvement is the degree to which employees immerse themselves in their jobs, invest time and energy in them, and view work as a central part of their overall lives". ${ }^{[23]}$ Keterlibatan kerja adalah sejauh mana pegawai melibatkan diri dalam pekerjaan mereka, menginvestasikan waktu dan energi di dalamnya, serta melihat pekerjaan sebagai bagian sentral dari kehidupan mereka secara keseluruhan.

Berdasarkan uraian di atas, dapat disintesiskan bahwa keterlibatan kerja adalah keterlibatan seseorang dalam pekerjaannya dan menganggap pekerjaannya merupakan bagian yang penting dalam hidupnya, dengan indikator: (1) dedikasi atas pekerjaan, (2) tingkat partisipasi, (3) kesempatan mengekspresikan diri, (4) kemampuan mengidentifikasi pekerjaan dan, (5) keikutsertaan dalam pekerjaan.

\section{Pengalaman Kerja}

Menurut Jennifer M. George and Gareth R. Jones (2012:192), "experienced meaningfulness of the work is the degree to which employees feel their jobs are important, worthwhile, and meaningful". ${ }^{[15]}$ Makna pengalaman kerja adalah sejauh mana karyawan merasa pekerjaan mereka penting, berharga, dan bermakna. Selanjutnya Nigel Nicholson (1998:120) mendefinisikan "the work experiences are jobs, seen as related from an external perspective and the outcome is being promoted. More broadly, an individual may hold a career within society, ranging across multiple occupations and organizations". [16] Pengalaman kerja adalah pekerjaan yang dipandang sebagai keterkaitan dari perspektif eksternal dan hasilnya sedang dipromosikan. Lebih luas, seorang individu dapat memegang karir dalam masyarakat, dari beberapa pekerjaan dan organisasi. Pengertian lain mengenai pengalaman kerja, salah satunya menurut Janice Rider Ellis and Celia Love Hartley (2012:138) yaitu, "work experience is of critical importance, and you should provide a meaningful employment history". ${ }^{[19]}$ Pengalaman kerja adalah hal yang sangat penting, dan anda harus memberikan riwayat pekerjaan yang bermakna Sedangkan menurut Michael Armstrong (2007:438), "work experience defined as: all the elements which contribute to providing you with an environment that enables you to optimise your contribution to the company and achieve your full potential, whilst maintaining a balance between your personal and professional life". ${ }^{6]}$ Pengalaman kerja didefinisikan sebagai: semua elemen yang 
berkontribusi untuk menyediakan anda dengan lingkungan yang memungkinkan anda untuk mengoptimalkan kontribusi anda kepada perusahaan dan mencapai potensi penuh anda, sementara mempertahankan keseimbangan antara kehidupan pribadi dan profesional anda.

Ricky W. Griffin and Gregory Moorhead (2014:130) menyatakan bahwa, "the three critical psychological states are experienced meaningfulness of the work the degree to which the individual experiences the job as generally meaningful, valuable, and worthwhile. Experienced responsibility for work outcomes the degree to which individual feel personality accountable and responsible for the results of their work, knowledge of result the degree to which individuals continuously understand how effectively they are performing the job". ${ }^{22]}$ Pengalaman sebagai kombinasi dari unsur aktif dan pasif. Dalam pengertian aktif, pengalaman adalah mencoba, dapat diartikan berhubungan erat dengan istilah percobaan. Dalam pengertian pasif, pengalaman adalah mengalami. Ketika mengalami sesuatu, seseorang bertindak atas hal tersebut, melakukan sesuatu dengan hal tersebut, kemudian mengalami konsekuensinya.

Berdasarkan uraian di atas, dapat disintesiskan bahwa pengalaman kerja adalah keterkaitan dari lingkungan dan riwayat kerja individu yang memungkinkan untuk mengoptimalkan kontribusinya kepada perusahaan dan mencapai potensi penuh, dengan indikator: (1) kontribusi kerja, (2) kebermaknaan kerja, (3) melaksanakan tugas dengan baik, (4) karakteristik pekerjaan, (5) adaptasi di lingkungan pekerjaan.

\section{METODOLOGI}

Penelitian ini bertujuan untuk menguji pengaruh langsung; (1) keterlibatan kerja terhadap komitmen organisasi, (2) pengalaman kerja terhadap komitmen organisasi, dan (3) keterlibatan kerja terhadap pengalaman kerja. Penelitian menggunakan metode survey dengan pendekatan teknik analisis jalur. Penelitian dilaksanakan di Sekretariat Badan Pengembangan Sumber Daya Manusia Kementerian Perhubungan RI. Populasi terjangkau penelitian ini sejumlah 128 pegawai. Sampel penelitian sebayak 97 orang. Analisa data untuk pengujian hipotesis akan dilakukan dengan menggunakan teknik analisis jalur, yaitu teknik yang diterapkan untuk menjelaskan pengaruh antara variabel-variabel penelitian. Sebelum dilaksanakan analisis jalur, uji signifikan regresi dan uji linearitas regresi sebagai prasyarat uji statistik dilakukan pengujian penormalan data dari masing-masing variabel penelitian dengan Uji-Liliefors, Statistik inferensial digunakan untuk menguji hipotesis tentang pengaruh antar variabel dengan menggunakan tehnik analisis jalur.

\section{LITERATURE REVIEW}

Beberapa penelitian yang relevan dengan penelitian ini adalah sebagai berikut:

1. Menurut Akyay Uygur dan Gonca Kilic, penelitian tentang Komitmen Organisasi dan Keterlibatan Kerja di Departemen Pusat Organisasi Kesehatan di Turki. Penelitian dilakukan pada 210 subyek, yang dipilih secara acak, dibagikan bentuk kuesioner. Dari kuesioner, 180 dari mereka (86\%) kembali dan 168 dari mereka dianggap sah dan dapat diterima dan dianalisis. Dari hasil penelitian tersebut, ditemukan sebuah korelasi positif moderat ditemukan antara komitmen organisasi dan keterlibatan kerja $(\mathrm{r}=$ $0,44)$. Dalam hal ini, ada korelasi yang signifikan antara komitmen organisasi dan keterlibatan kerja, meskipun tidak sangat kuat. ${ }^{[24]}$ 
2. Menurut Magid Igbaria, Saroj Parasuraman, Michael K. Badawy, penelitian tentang Pengalaman Kerja, Keterlibatan Kerja, Dan Kualitas Kehidupan Kerja dalam Sistem Informasi Personal. Penelitian ini menilai keterlibatan kerja dari 464 profesional dan manajer dalam sistem informasi (IS) lapangan. Temuan menunjukkan bahwa keterlibatan berfungsi sebagai peran moderator kompleks dalam pola hubungan pengalaman kerja, dan karakteristik pekerjaan dengan harapan karir dan hasil karir. Hal ini baik linear dan hubungan non-linear dengan beberapa variabel penelitian. Sementara dalam beberapa kasus, tingginya tingkat keterlibatan kerja cenderung meningkatkan efek menguntungkan dari pengalaman kerja pada kualitas kehidupan kerja, di lain keterlibatan tersebut cenderung meningkatkan efek negatif dari stres peran. Implikasi dari temuan dan arah untuk penelitian masa depan dibahas.[25]

3. Menurut Gurukula Kangri Vishwavidyalaya, penelitian ini mengeksplorasi dampak komitmen organisasi dan keterlibatan pekerjaan pada kinerja organisasi dalam organisasi kesehatan. Kuesioner yang digunakan dalam penelitian ini terdiri dari tiga variabel pelibatan kerja oleh Rich, LePine dan Crawford (2010) dan tiga variabel komitmen oleh Allen dan Meyer (2011) diambil sebagai variabel independen sementara self frame empat dimensi kinerja organisasi sebagai variabel dependen. Data dikumpulkan melalui kuesioner terstruktur yang berisi skala Likert lima poin. Sampel untuk penelitian ini terdiri dari 250 profesional perawatan kesehatan dari 35 rumah sakit dan panti jompo. Simple random sampling digunakan sebagai teknik sampling dan penelitian ini adalah ex-post di alam. Data dianalisis menggunakan mean \& standar deviasi, korelasi dan regresi berganda. Hasil penelitian menunjukkan bahwa keterlibatan pekerjaan dan komitmen organisasi secara signifikan berkorelasi dengan kinerja organisasi perawatan kesehatan. Komitmen organisasi dan keterlibatan pekerjaan memiliki dampak yang signifikan terhadap kinerja organisasi kesehatan.

4. Menurut Eka Mariyanti, yang meneliti tentang Pengaruh Keterlibatan Kerja dan Kepuasan Kerja Terhadap Komitmen Organisasi (Studi Kasus Pada Perawat Rumah Sakit Swasta Di Kota Padang). Penelitian ini bertujuan untuk menganalisis pengaruh keterlibatan kerja dan kepuasan kerja terhadap komitmen organisasi pada perawat rumah sakit swasta dikota padang, data dikumpulkan dengan menggunakan kuesioner yang dibagikan kepada 200 orang perawat dengan menggunakan purposive sampling yang mana sampel penelitian dipilih dengan kriteria tertentu, hasilnya menunjukkan bahwa keterlibatan kerja berpengaruh positif dan signifikan terhadap komitmen organisasi sedangkan kepuasan kerja tidak berpengaruh signifikan terhadap komitmen organisasi.

5. Menurut Maria Finsensia Ansel, dan Sutarto Wijono, melakukan penelitian tentang Pengaruh Keterlibatan Kerja dan Kepuasan Kerja Terhadap Komitmen Organisasi Polisi Di Kepolisian Resor (Polres) Ende, Tujuan dari penelitian ini adalah untuk menentukan signifikansi efek simultan dari keterlibatan pekerjaan dan kepuasan kerja terhadap komitmen organisasi kepolisian Kepolisian Ende. Subjeknya adalah polisi di Polres Ende yang mana berjumlah 300 orang, dengan sampel sebanyak 75 orang. Penelitian instrumen yang digunakan dalam Metode pengumpulan data adalah skala keterlibatan pekerjaan, pekerjaan skala kepuasan dan skala komitmen organisasi. Pengujian hipotesis menggunakan analisis regresi linier berganda menemukan nilai koefisien tekad ( $R 2) 0,360, F=20,244$, dengan signifikansi $p=0,000(p<0,05)$. Hasil uji regresi berganda menunjukkan ada secara simultan signifikan dan pengaruh 
keterlibatan positif dari keterlibatan pekerjaan dan kepuasan kerja komitmen berorganisasi.

\section{HASIL DAN PEMBAHASAN}

Berdasarkan tinjauan pustaka yang telah dibahas dan kajian empiris di atas, berikut dibahas hasil penelitian sebagai upaya untuk melakukan sintesis antara kajian teori dengan temuan empiris. Adapun secara rinci pembahasan hasil analisis dan pengujian hipotesis penelitian diuraikan sebagai berikut:

\section{Uji Signifikansi dan Linearitas Persamaan Regresi Komitmen Organisasi atas Keterlibatan Kerja}

Dari data hasil perhitungan untuk penyusunan model persamaan regresi antara komitmen organisasi dengan keterlibatan kerja pada lampiran 5 diperoleh konstanta regresi a $=71,17$ dan koefisien regresi $\mathrm{b}=0,34$. Dengan demikian hubungan model persamaan regresi sederhana adalah $=71,17+0,34 \mathrm{X} 1$. Sebelum model persamaan regresi tersebut dianalisis lebih lanjut dan digunakan dalam menarik kesimpulan, terlebih dahulu dilakukan uji signifikansi dan linearitas persamaan regresi. Hasil perhitungan uji signifikansi dan linearitas disusun pada tabel ANAVA seperti pada tabel berikut:

Tabel 1.1 ANAVA untuk Uji Signifikansi dan Linearitas Persamaan Regresi $\hat{\mathbf{X}}_{\mathbf{3}}=\mathbf{7 1 , 1 7}$ $+\mathbf{0 , 3 4 X _ { 1 }}$

\begin{tabular}{|c|c|c|c|c|c|c|}
\hline \multirow[b]{2}{*}{ Sumber Varians } & \multirow[b]{2}{*}{ dk } & \multirow[b]{2}{*}{$\begin{array}{c}\text { Jumlah } \\
\text { Kuadrat (JK) }\end{array}$} & \multirow{2}{*}{$\begin{array}{c}\text { Rata-rata } \\
\text { Jumlah } \\
\text { Kuadrat } \\
\text { (RJK) }\end{array}$} & \multirow[b]{2}{*}{$\mathbf{F}_{\text {hitung }}$} & \multicolumn{2}{|c|}{$\mathbf{F}_{\text {tabel }}$} \\
\hline & & & & & $\alpha=\mathbf{0 , 0 5}$ & $\alpha=\mathbf{0 , 0 1}$ \\
\hline Total & 97 & 1334627 & & & & \\
\hline Regresi a & 1 & 1331579,64 & & & & \\
\hline Regresi b/a & 1 & 552,26 & 552,26 & $21,03 * *$ & 3,94 & 6,91 \\
\hline Residu & 95 & 2495,10 & 26,26 & & & \\
\hline Tuna Cocok & 27 & 472,36 & 17,49 & $0,59^{\mathrm{ns}}$ & 1,65 & 2,03 \\
\hline Galat & 68 & 2022,74 & 29,75 & & & \\
\hline
\end{tabular}

Keterangan :

** : Regresi sangat signifikan $(21,03>6,91$ pada $\alpha=0,01)$

ns : Regresi berbentuk linear $(0,59<1,65$ pada $\alpha=0,05)$

$\mathrm{dk}$ : Derajat kebebasan

JK : Jumlah kuadrat

RJK : Rata-rata jumlah kuadrat

Persamaan regresi $\hat{X}_{3}=71,17+0,34 \mathrm{X}_{1}$, untuk uji signifikansi diperoleh $\mathrm{F}_{\text {hitung }} 21,03$ lebih besar dari pada $F_{\text {tabel }(0,01 ; 1: 95)} 6,91$ pada $\alpha=0,01$. Karena $F_{\text {hitung }}>F_{\text {tabel }}$ maka persamaan regresi dinyatakan sangat signifikan. Untuk uji linearitas diperoleh $F_{\text {hitung }}$ sebesar 0,59 lebih kecil dari pada $F_{\text {tabel }(0,05 ; 27: 68)}$ sebesar 1,65 pada $\alpha=0,05$. Karena $F_{\text {hitung }}<F_{\text {tabel }}$ maka sebaran titik yang terestimasi membentuk garis linear dapat diterima. Secara visual dapat dilihat pada gambar berikut: 


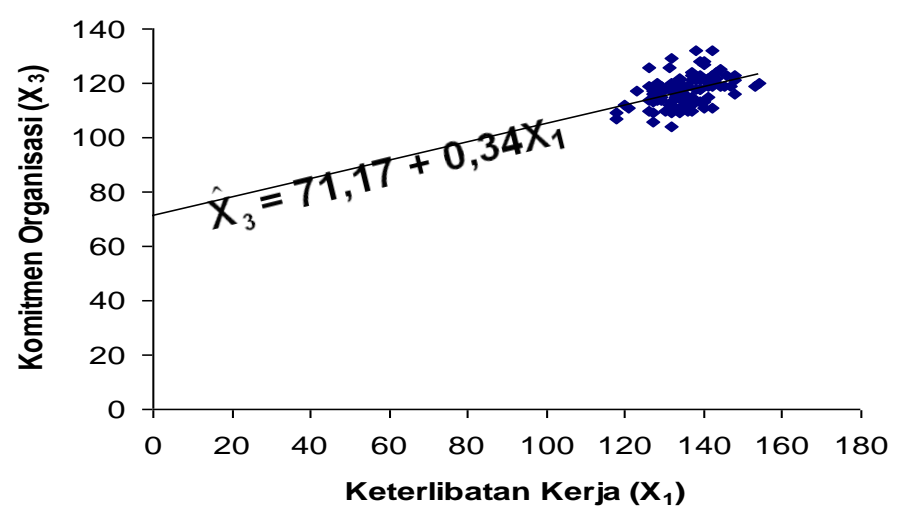

Gambar 1.1 Grafik Persamaan Regresi $\hat{\mathbf{X}}_{3}=71,17+\mathbf{0 , 3 4 \mathrm { X } _ { 1 }}$

\section{Uji Signifikansi dan Linearitas Persamaan Regresi Komitmen Organisasi atas Pengalaman Kerja}

Dari data hasil perhitungan untuk penyusunan model persamaan regresi antara komitmen organisasi dengan pengalaman kerja pada lampiran 5, diperoleh konstanta regresi a $=77,06$ dan koefisien regresi $\mathrm{b}=0,30$. Dengan demikian hubungan model persamaan regresi sederhana adalah $=77,06+0,30 \mathrm{X} 2$. Sebelum model persamaan regresi tersebut dianalisis lebih lanjut dan digunakan dalam menarik kesimpulan, terlebih dahulu dilakukan uji signifikansi dan linearitas persamaan regresi. Hasil perhitungan uji signifikansi dan linearitas disusun pada tabel ANAVA seperti berikut:

Tabel 1.2 ANAVA untuk Uji Signifikansi dan Linearitas Persamaan Regresi $=$ 77,06 + 0,30X2

\begin{tabular}{|c|c|c|c|c|c|c|}
\hline \multirow[b]{2}{*}{ Sumber Varians } & \multirow[b]{2}{*}{ dk } & \multirow{2}{*}{$\begin{array}{c}\text { Jumlah } \\
\text { Kuadrat } \\
\text { (JK) }\end{array}$} & \multirow{2}{*}{$\begin{array}{c}\text { Rata-rata } \\
\text { Jumlah } \\
\text { Kuadrat (RJK) }\end{array}$} & \multirow[b]{2}{*}{$\mathbf{F}_{\text {hitung }}$} & \multicolumn{2}{|c|}{$F_{\text {tabel }}$} \\
\hline & & & & & $\alpha=\mathbf{0 , 0 5}$ & $\alpha=\mathbf{0 , 0 1}$ \\
\hline Total & 97 & 1334627 & & & & \\
\hline Regresi a & 1 & 1331579,64 & & & & \\
\hline Regresi b/a & 1 & 534,90 & 534,90 & $20,23 * *$ & 3,94 & 6,91 \\
\hline Residu & 95 & 2512,46 & 26,45 & & & \\
\hline Tuna Cocok & 29 & 692,44 & $\begin{array}{l}23,88 \\
27,58\end{array}$ & $0,87^{\mathrm{ns}}$ & 1,64 & 2,01 \\
\hline Galat & 66 & 1820,02 & 27. & & & \\
\hline
\end{tabular}

Keterangan :

** : Regresi sangat signifikan $(20,23>6,91$ pada $\alpha=0,01)$

ns $\quad$ : Regresi berbentuk linear $(0,87<1,64$ pada $\alpha=0,05)$

dk : Derajat kebebasan

JK : Jumlah kuadrat

RJK : Rata-rata jumlah kuadrat

Persamaan regresi $\hat{X}_{3}=77,06+0,30 X_{2}$, untuk uji signifikansi diperoleh $F_{\text {hitung }} 20,23$ lebih besar dari pada $F_{\text {tabel }(0,01 ; 1: 95)} 6,91$ pada $\alpha=0,01$. Karena $F_{\text {hitung }}>F_{\text {tabel }}$ maka persamaan regresi dinyatakan sangat signifikan. Untuk uji linearitas diperoleh $F_{\text {hitung }}$ sebesar 0,87 lebih kecil dari pada $F_{\text {tabel }(0,05 ; 29: 66)}$ sebesar 1,64 pada $\alpha=0,05$. Karena $F_{\text {hitung }}<F_{\text {tabel }}$ maka sebaran titik yang terestimasi membentuk garis linear dapat diterima. Secara visual dapat dilihat pada gambar berikut: 


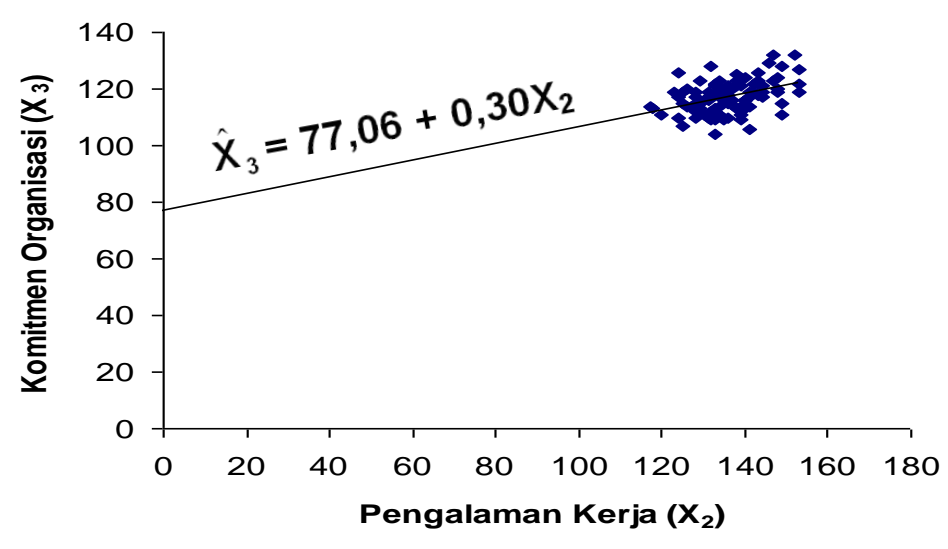

Gambar 1.2 Grafik Persamaan Regresi $\hat{\mathbf{X}}_{3}=77,06+0,30 \mathrm{X}_{2}$

Uji Signifikansi dan Linearitas Persamaan Regresi Pengalaman Kerja atas Keterlibatan Kerja

Dari data hasil perhitungan untuk penyusunan model persamaan regresi antara pengalaman kerja dengan keterlibatan kerja pada lampiran 5 diperoleh konstanta regresi a $=$ 88,30 dan koefisien regresi $b=0,35$. Dengan demikian hubungan model persamaan regresi sederhana adalah $\hat{\mathrm{X}}_{2}=88,30+0,35 \mathrm{X}_{1}$. Sebelum model persamaan regresi tersebut dianalisis lebih lanjut dan digunakan dalam menarik kesimpulan, terlebih dahulu dilakukan uji signifikansi dan linearitas persamaan regresi. Hasil perhitungan uji signifikansi dan linearitas disusun pada tabel ANAVA seperti berikut:

Tabel 1.3 ANAVA untuk Uji Signifikansi dan Linearitas Persamaan Regresi $\hat{\mathbf{X}}_{\mathbf{2}}=\mathbf{8 8 , 3 0}$ $+\mathbf{0 , 3 5 X _ { 1 }}$

\begin{tabular}{|c|c|c|c|c|c|c|}
\hline \multirow[b]{2}{*}{ Sumber Varians } & \multirow[b]{2}{*}{$\mathbf{d k}$} & \multirow[b]{2}{*}{$\begin{array}{c}\text { Jumlah } \\
\text { Kuadrat (JK) }\end{array}$} & \multirow{2}{*}{$\begin{array}{c}\text { Rata-rata } \\
\text { Jumlah } \\
\text { Kuadrat } \\
\text { (RJK) }\end{array}$} & \multirow[b]{2}{*}{$\mathbf{F}_{\text {hitung }}$} & \multicolumn{2}{|c|}{$\mathbf{F}_{\text {tabel }}$} \\
\hline & & & & & $\alpha=\mathbf{0 , 0 5}$ & $\alpha=\mathbf{0 , 0 1}$ \\
\hline Total & 97 & 1797265 & & & & \\
\hline Regresi a & 1 & 1791121,25 & & & & \\
\hline Regresi b/a & 1 & 591,41 & 591,41 & $10,12 * *$ & 3,94 & 6,91 \\
\hline Residu & 95 & 5552,34 & 58,45 & & & \\
\hline $\begin{array}{l}\text { Tuna Cocok } \\
\text { Galat }\end{array}$ & $\begin{array}{l}27 \\
68\end{array}$ & $\begin{array}{l}1829,08 \\
3723,26\end{array}$ & $\begin{array}{l}67,74 \\
54,75\end{array}$ & $1,24^{\mathrm{ns}}$ & 1,65 & 2,03 \\
\hline
\end{tabular}

Keterangan :

** : Regresi sangat signifikan $(10,12>6,91$ pada $\alpha=0,01)$

ns : Regresi berbentuk linear $(1,24<1,65$ pada $\alpha=0,05)$

$\mathrm{dk}$ : Derajat kebebasan

JK : Jumlah kuadrat

RJK : Rata-rata jumlah kuadrat

Persamaan regresi $\hat{X}_{2}=88,30+0,35 \mathrm{X}_{1}$, untuk uji signifikansi diperoleh $\mathrm{F}_{\text {hitung }} 10,12$ lebih besar dari pada $F_{\text {tabel }(0,01 ; 1: 95)} 6,91$ pada $\alpha=0,01$. Karena $F_{\text {hitung }}>F_{\text {tabel }}$ maka persamaan regresi dinyatakan sangat signifikan. Untuk uji linearitas diperoleh $F_{\text {hitung }}$ sebesar 1,24 lebih kecil dari pada $F_{\text {tabel }(0,05 ; 27: 68)}$ sebesar 1,65 pada $\alpha=0,05$. Karena $F_{\text {hitung }}<F_{\text {tabel }}$ maka sebaran titik yang terestimasi membentuk garis linear dapat diterima. Secara visual dapat dilihat pada gambar 4.6. 


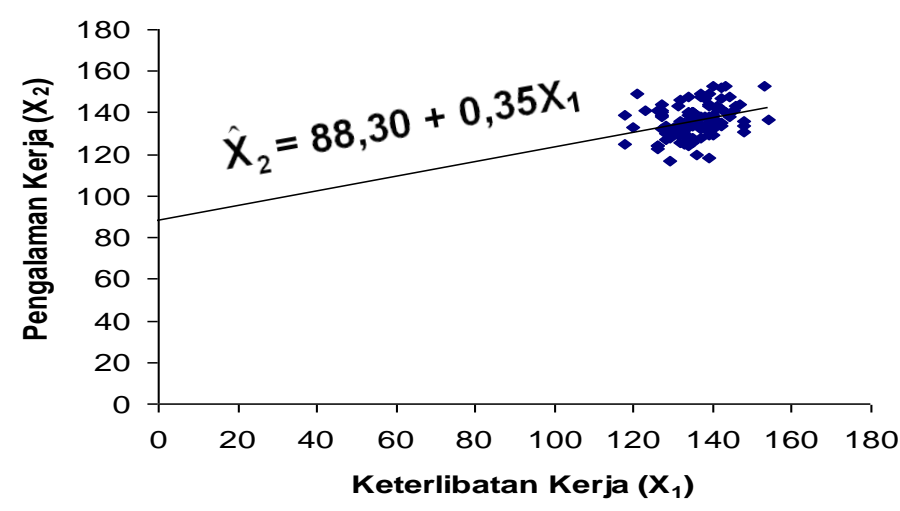

Gambar 1.3 Grafik Persamaan Regresi $\hat{X}_{2}=88,30+0,35 X_{1}$ ini.

Keseluruhan hasil uji signifikansi dan linearitas regresi dirangkum pada tabel berikut

Tabel 1.4 Hasil Uji Signifikansi dan Uji Linearitas Regresi

\begin{tabular}{|c|c|c|c|c|c|c|}
\hline \multirow[b]{2}{*}{ Reg } & \multirow[b]{2}{*}{ Persamaan } & \multicolumn{2}{|c|}{ Uji Regresi } & \multicolumn{2}{|c|}{ Uji Linearitas } & \multirow[b]{2}{*}{ Kesimpulan } \\
\hline & & $\mathrm{F}_{\text {hitung }}$ & $\begin{array}{c}F_{\text {tabel }} \\
\alpha=0,01\end{array}$ & $F_{\text {hitung }}$ & $\begin{array}{c}F_{\text {tabel }} \\
\alpha= \\
0,05\end{array}$ & \\
\hline $\begin{array}{l}\mathrm{X}_{3} \\
\text { atas } \\
\mathrm{X}_{1} \\
\end{array}$ & $\hat{X}_{3}=71,17+0,34 X_{1}$ & $21,03 * *$ & 6,91 & $0,59^{\mathrm{ns}}$ & 1,65 & $\begin{array}{l}\text { Regresi sangat } \\
\text { signifikan/ } \\
\text { Regresi linear }\end{array}$ \\
\hline $\begin{array}{l}X_{3} \\
\text { atas } \\
X_{2} \\
\end{array}$ & $\hat{X}_{3}=77,06+0,30 X_{2}$ & $20,23 * *$ & 6,91 & $0,87^{\mathrm{ns}}$ & 1,64 & \begin{tabular}{|l|} 
Regresi sangat \\
signifikan/ \\
Regresi linear
\end{tabular} \\
\hline $\begin{array}{l}\mathrm{X}_{2} \\
\text { atas } \\
\mathrm{X}_{1}\end{array}$ & $\hat{\mathrm{X}}_{2}=88,30+0,35 \mathrm{X}_{1}$ & $10,12 * *$ & 6,91 & $1,24^{\mathrm{ns}}$ & 1,65 & $\begin{array}{l}\text { Regresi sangat } \\
\text { signifikan/ } \\
\text { Regresi linear }\end{array}$ \\
\hline
\end{tabular}

Keterangan :

** : Sangat signifikan

ns : Non signifikan (regresi linear)

Dari hasil analisis pada bagian terdahulu dan proses perhitungan yang dilakukan dapat dirangkum sebagai berikut:

Tabel 1.5 Matriks Koefisien Korelasi Sederhana antar Variabel

\begin{tabular}{|c|c|c|c|}
\hline \multirow{2}{*}{ Matrik } & \multicolumn{3}{|c|}{ Koefisien Korelasi } \\
\cline { 2 - 4 } & $\mathbf{X}_{\mathbf{1}}$ & $\mathbf{X}_{\mathbf{2}}$ & $\mathbf{X}_{\mathbf{3}}$ \\
\hline $\mathbf{X}_{\mathbf{1}}$ & 1,00 & 0,310 & 0,426 \\
\hline $\mathbf{X}_{\mathbf{2}}$ & & 1,00 & 0,419 \\
\hline $\mathbf{X}_{\mathbf{3}}$ & & & 1,00 \\
\hline
\end{tabular}

Dari tabel di atas dapat terlihat bahwa korelasi antara keterlibatan kerja dengan pengalaman kerja sebesar 0,310. Korelasi antara keterlibatan kerja dengan komitmen organisasi sebesar 0,426. Korelasi antara pengalaman kerja dengan komitmen organisasi sebesar 0,419 .

\section{Pengaruh Keterlibatan Kerja terhadap Komitmen Organisasi}

Dari hasil pengujian hipotesis pertama dapat disimpulkan bahwa terdapat pengaruh langsung positif keterlibatan kerja terhadap komitmen organisasi dengan nilai koefisien 
korelasi sebesar 0,426 dan nilai koefisien jalur sebesar 0,328. Ini memberikan makna keterlibatan kerja berpengaruh langsung terhadap komitmen organisasi.

Hasil penelitian ini senada dengan pendapat beberapa ahli di antaranya adalah Steve M. Jex (2010:126) menyatakan bahwa, "for job involvement and organizational commitment, this affect is positive". ${ }^{[14]}$ Keterlibatan kerja dan komitmen organisasi, berpengaruh langsung positif. Selanjutnya menurut Aaron Cohen (2009:103) menyatakan bahwa, "job involvement in particular exerts a powerful influence on commitment to the organization." "[3] Keterlibatan kerja khususnya memberikan pengaruh kuat pada komitmen terhadap organisasi. Adapun menurut Joan E. Pynes (2009:124) berpendapat bahwa, "dailey found that work autonomy, job involvement, and feedback from the work itself were strong predictors of organizational commitment". ${ }^{[12]}$ Dailey menemukan bahwa otonomi kerja, keterlibatan kerja, dan umpan balik dari pekerjaan itu sendiri adalah prediktor kuat dari komitmen organisasi.

Keterlibatan kerja berpengaruh langsung positif terhadap komitmen organisasi.

$\mathrm{H}_{0}: \beta_{31} \leq 0$

$\mathrm{H}_{1}: \beta_{31}>0$

$\mathrm{H}_{0}$ ditolak, jika $\mathrm{t}_{\text {hitung }}>\mathrm{t}_{\text {tabel }}$.

Dari hasil perhitungan analisis jalur, pengaruh langsung keterlibatan kerja terhadap komitmen organisasi, nilai koefisien jalur sebesar 0,328 dan nilai $t_{\text {hitung }}$ sebesar 3,54. Nilai $\mathrm{t}_{\text {tabel }}$ untuk $\alpha=0,01$ sebesar 2,63. Oleh karena nilai $\mathrm{t}_{\text {hitung }}$ lebih besar dari pada nilai $\mathrm{t}_{\text {tabel }}$ maka dengan demikian $\mathrm{H}_{0}$ ditolak dan $\mathrm{H}_{1}$ diterima yaitu bahwa keterlibatan kerja berpengaruh secara langsung terhadap komitmen organisasi dapat diterima.

Hasil analisis hipotesis pertama memberikan temuan bahwa keterlibatan kerja berpengaruh secara langsung positif terhadap komitmen organisasi. Dengan demikian dapat disimpulkan bahwa komitmen organisasi dipengaruhi secara langsung positif oleh keterlibatan kerja. Meningkatnya keterlibatan kerja mengakibatkan peningkatan komitmen organisasi.

Tabel 1.6 Koefisien Jalur Pengaruh $X_{1}$ terhadap $X_{3}$

\begin{tabular}{|c|c|c|c|c|}
\hline \multirow{2}{*}{$\begin{array}{c}\text { Pengaruh } \\
\text { langsung }\end{array}$} & \multirow{2}{*}{ Koefisien Jalur } & \multirow{2}{*}{$\mathrm{t}_{\text {hitung }}$} & $\alpha=0,05$ & $\alpha=0,01$ \\
\cline { 3 - 5 } & & $3,54^{* *}$ & 1,99 & 2,63 \\
\hline $\mathrm{X}_{1}$ terhadap $\mathrm{X}_{3}$ & 0,328 & $\mathrm{t}_{\text {tabel }}$ \\
\hline
\end{tabular}

** Koefisien jalur sangat signifikan $(3,54>2,63$ pada $\alpha=0,01)$

\section{Pengaruh Pengalaman Kerja terhadap Komitmen Organisasi}

Dari hasil pengujian hipotesis kedua dapat disimpukan bahwa terdapat pengaruh langsung positif pengalaman kerja terhadap komitmen organisasi dengan nilai koefisien korelasi sebesar 0,419 dan nilai koefisien jalur sebesar 0,317. Ini memberikan makna pengalaman kerja berpengaruh langsung terhadap komitmen organisasi.

Hasil penelitian ini senada dengan pendapat beberapa ahli di antaranya adalah Jenai Mynatt (2009:124) menyatakan bahwa, "additionally research indicates that employees with positive mentoring experiences typically feel higher levels of pay satisfaction, career satisfaction, and organizational commitment". [13] Selain itu penelitian menunjukkan bahwa pegawai dengan pengalaman mentoring positif biasanya merasa tingkat kepuasan gaji, kepuasan karir, dan komitmen organisasi. Adapun menurut David G. Collings and Geoffrey Wood (2009:173) menyatakan bahwa, "employees are likely to enjoy a high degree of task discretion and stable earnings, allowing for a more satisfying work experience, deepening organizational commitment". ${ }^{[9]}$ Pegawai cenderung untuk menikmati tingkat tinggi tugas 
kebijaksanaan dan pendapatan yang stabil, memungkinkan untuk pengalaman kerja lebih memuaskan, memperdalam komitmen organisasi. Selanjutnya menurut Joseph E. Champoux (2011:106) mengemukakan bahwa, "the most common work attitudes studied by researchers are organizational commitment, satisfaction, and job involvement. These attitudes are important aspects of work experiences and play a role in employee turnover". ${ }^{[1]}$ Sikap kerja yang paling umum dipelajari oleh peneliti adalah komitmen organisasi, kepuasan, dan keterlibatan kerja. Sikap ini merupakan aspek penting dari pengalaman kerja dan berperan dalam pergantian pegawai.

Pengalaman kerja berpengaruh langsung positif terhadap komitmen organisasi.

$\mathrm{H}_{0}: \beta_{32} \leq 0$

$\mathrm{H}_{1}: \beta_{32}>0$

$\mathrm{H}_{0}$ ditolak, jika $\mathrm{t}_{\text {hitung }}>\mathrm{t}_{\text {tabel }}$.

Dari hasil perhitungan analisis jalur, pengaruh langsung pengalaman kerja terhadap komitmen organisasi, nilai koefisien jalur sebesar 0,317 dan nilai $t_{\text {hitung }}$ sebesar 3,43. Nilai $\mathrm{t}_{\text {tabel }}$ untuk $\alpha=0,01$ sebesar 2,63. Oleh karena nilai $\mathrm{t}_{\text {hitung }}$ lebih besar dari pada nilai $\mathrm{t}_{\text {tabel }}$ maka $\mathrm{H}_{0}$ ditolak dan $\mathrm{H}_{1}$ diterima, dengan demikian pengalaman kerja berpengaruh secara langsung terhadap komitmen organisasi dapat diterima.

Hasil analisis hipotesis kedua menghasilkan temuan bahwa pengalaman kerja berpengaruh secara langsung positif terhadap komitmen organisasi. Berdasarkan hasil temuan tersebut dapat disimpulkan bahwa komitmen organisasi dipengaruhi secara langsung positif oleh pengalaman kerja. Meningkatnya pengalaman kerja mengakibatkan peningkatan komitmen organisasi.

Tabel 1.7 Koefisien Jalur Pengaruh $X_{2}$ terhadap $X_{3}$

\begin{tabular}{|c|c|c|c|c|}
\hline \multirow{2}{*}{$\begin{array}{c}\text { Pengaruh } \\
\text { langsung }\end{array}$} & \multirow{2}{*}{ Koefisien Jalur } & \multirow{2}{*}{$\mathrm{t}_{\text {hitung }}$} & \multicolumn{2}{|c|}{$\mathrm{t}_{\text {tabel }}$} \\
\cline { 4 - 5 } & & & $\alpha=0,05$ & $\alpha=0,01$ \\
\hline $\mathrm{X}_{2}$ terhadap $\mathrm{X}_{3}$ & 0,317 & $3,43 * *$ & 1,99 & 2,63 \\
\hline
\end{tabular}

$* *$ Koefisien jalur sangat signifikan $(3,43>2,63$ pada $\alpha=0,01)$

\section{Pengaruh Keterlibatan Kerja terhadap Pengalaman Kerja}

Dari hasil pengujian hipotesis ketiga dapat disimpulkan bahwa terdapat pengaruh langsung positif keterlibatan kerja terhadap pengalaman kerja dengan nilai koefisien korelasi sebesar 0,310 dan nilai koefisien jalur sebesar 0,310. Ini memberikan makna keterlibatan kerja berpengaruh langsung terhadap pengalaman kerja.

Hasil penelitian ini senada dengan pendapat beberapa ahli di antaranya adalah menurut Aaron Cohen (2009:124) menyatakan bahwa, "job involvement is strongly affected by, and can be perceived as a reflection of work experiences. The more positive these experiences, the higher the job involvement". "Keterlibatan kerja sangat dipengaruhi oleh, dan bisa dianggap sebagai cerminan pengalaman kerja. Semakin positif pengalaman ini, semakin tinggi keterlibatan kerja. Menurut Schermerhorn, Hunt, and Osborn (2010:6) berpendapat bahwa, "outcome or dependent variables studied by researchers, for example, include task performance, job satisfaction, job involvement, absenteeism, and turnover. It is in this sense that $O B$ is an applied social science that can ultimately help to improve the functioning of organizations and the work experiences of their members. ${ }^{,[5]}$ Variabel hasil yang dipelajari oleh para peneliti, misalnya, kinerja tugas, kepuasan kerja, keterlibatan kerja, absensi, dan 
omset. Hal ini dalam pengertian OB adalah ilmu sosial terapan yang pada akhirnya dapat membantu untuk meningkatkan fungsi organisasi dan pengalaman kerja dari anggota mereka. Selanjutnya menurut Joseph E. Champoux (2011:123) mengemukakan bahwa, "the most common work attitudes studied by researchers are organizational commitment, satisfaction, and job involvement. These attitudes are important aspects of work experiences and play a role in employee turnover." ${ }^{[11]}$ Sikap kerja yang paling umum dipelajari oleh peneliti adalah komitmen organisasi, kepuasan, dan keterlibatan kerja. Sikap ini merupakan aspek penting dari pengalaman kerja dan berperan dalam pergantian pegawai.

Keterlibatan kerja berpengaruh langsung positif terhadap pengalaman kerja.

$\mathrm{H}_{0}: \beta_{21} \leq 0$

$\mathrm{H}_{1}: \beta_{21}>0$

$\mathrm{H}_{0}$ ditolak, jika $\mathrm{t}_{\text {hitung }}>\mathrm{t}_{\text {tabel }}$.

Dari hasil perhitungan analisis jalur, pengaruh langsung keterlibatan kerja terhadap pengalaman kerja, nilai koefisien jalur sebesar 0,310 dan nilai $t_{\text {hitung }}$ sebesar 3,18. Nilai $t_{\text {tabel }}$ untuk $\alpha=0,01$ sebesar 2,63 . Oleh karena nilai $t_{\text {hitung }}$ lebih besar dari pada nilai $t_{\text {tabel }}$ maka dengan demikian $\mathrm{H}_{0}$ ditolak dan $\mathrm{H}_{1}$ diterima yaitu bahwa keterlibatan kerja berpengaruh secara langsung terhadap pengalaman kerja dapat diterima.

Hasil analisis hipotesis ketiga memberikan temuan bahwa keterlibatan kerja berpengaruh secara langsung positif terhadap pengalaman kerja. Dengan demikian dapat disimpulkan bahwa pengalaman kerja dipengaruhi secara langsung positif oleh keterlibatan kerja. Meningkatnya keterlibatan kerja mengakibatkan peningkatan pengalaman kerja.

Tabel 1.8 Koefisien Jalur Pengaruh $X_{1}$ terhadap $X_{2}$

\begin{tabular}{|c|c|c|c|c|}
\hline \multirow{2}{*}{$\begin{array}{c}\text { Pengaruh } \\
\text { langsung }\end{array}$} & \multirow{2}{*}{ Koefisien Jalur } & \multirow{2}{*}{$\mathrm{t}_{\text {hitung }}$} & \multicolumn{2}{|c|}{$\mathrm{t}_{\text {tabel }}$} \\
\cline { 4 - 5 } & & $\alpha=0,05$ & $\alpha=0,01$ \\
\hline $\mathrm{X}_{1}$ terhadap $\mathrm{X}_{2}$ & 0,310 & $3,18 * *$ & 1,99 & 2,63 \\
\hline
\end{tabular}

$* *$ Koefisien jalur sangat signifikan $(3,18>2,63$ pada $\alpha=0,01)$

Ringkasan model analisis jalur dapat terlihat pada gambar 4.7 sebagai berikut:

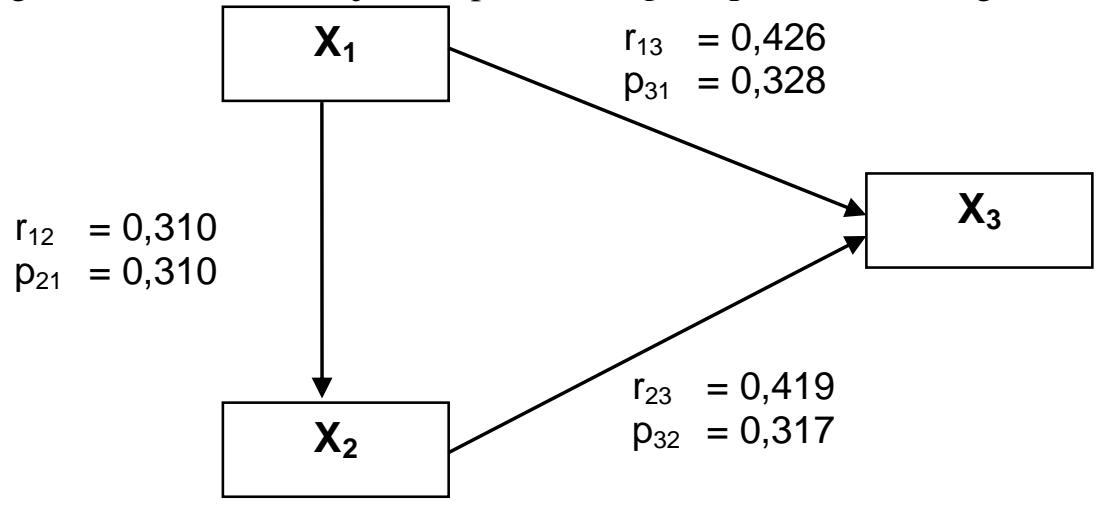

Gambar 1.4 Model Empiris Antar Variabel 


\section{KESIMPULAN DAN SARAN}

\section{KESIMPULAN}

Berdasarkan hasil pengujian hipotesis dan dan pembahasan yang telah dikemukakan diperoleh kesimpulan penelitian sebagai berikut: (1) keterlibatan kerja berpengaruh langsung positif terhadap komitmen organisasi, hal ini menunjukkan bahwa keterlibatan kerja yang tinggi akan meningkatkan komitmen organisasi, semakin tinggi keterlibatan kerja maka akan semakin baik komitmen organisasi pegawai di Sekretariat Badan Pengembangan Sumber Daya Manusia Kementerian Perhubungan RI. (2) pengalaman kerja berpengaruh langsung positif terhadap komitmen organisasi, hal ini menunjukkan bahwa pengalaman kerja yang tinggi akan meningkatkan komitmen organisasi, semakin tinggi pengalaman kerja maka akan semakin baik komitmen organisasi pegawai di Sekretariat Badan Pengembangan Sumber Daya Manusia Kementerian Perhubungan RI. (3) keterlibatan kerja berpengaruh langsung positif terhadap pengalaman kerja, hal ini menunjukkan bahwa keterlibatan kerja yang tinggi akan meningkatkan pengalaman kerja, pengakuan atas kerja pegawai dan pemberian apresiasi atas hasil kerja pegawai.

\section{SARAN}

Berdasarkan kesimpulan dan implikasi di atas, beberapa saran yang dapat disampaikan peneliti adalah sebagai berikut: (1) Bagi Kepala Badan Pengembangan Sumber Daya Manusia Perhubungan sebagai pemimpin tertinggi sekaligus contoh bagi para pegawai agar mampu membimbing, mengarahkan serta meningkatkan tanggung jawab serta rasa kepemilikan yang tinggi terhadap organisasi dan sikap peduli terhadap tugas sebagai pegawai, menciptakan sistem penghargaan yang mampu menghasilkan kualitas pegawai dengan semangat kerja yang tinggi, memiliki target dalam bekerja, patuh terhadap peraturan yang berlaku, serta memperhatikan kesejahteraan para pegawai serta membuat suasana kerja yang nyaman, harmonis, serta kondusif sehingga mampu mendorong para pegawai untuk bersedia memberikan loyalitasnya dan melakukan tugas melebihi tugas formalnya sebagai pegawai. (2) Bagi para pegawai agar memandang bahwa dalam melaksanakan tugas pokoknya sehari-hari sebagai pegawai harus memiliki motivasi internal serta kecintaan terhadap pekerjaan yang dijalani, sehingga para pegawai dapat merasakan adanya ketulusan dan keikhlasan terhadap profesi, tanggung jawab serta kepemilikan yang akan mendorong dirinya untuk melakukan pekerjaannya sebaik mungkin serta melebihi tugas formalnya. Sikap seperti inilah yang akan melahirkan seorang pegawai yang memiliki keterlibatan kerja yang tinggi. (3) Bagi para peneliti lain agar penelitian ini dapat dijadikan rujukan dalam penelitian lanjutan terkait komitmen organisasi karena ruang lingkup penelitian ini terbatas keterlibatan kerja dan pengalaman kerja pegawai.

\section{DAFTAR PUSTAKA}

[1] Hasil informasi yang diperoleh dari Kepala Dinas Pendidikan Kabupaten Bekasi, 17 Januari 2016. Retrieved from Hasil informasi yang diperoleh dari Kepala Dinas Pendidikan Kabupaten Bekasi, 17 Januari 2016.

\section{[2] https://www.researchgate.net/publication/306014890_The_Impact_of_Job_Engagement_a nd_Organizational_Commitment_on_Organisational_Performance. (diakses pada tanggal 15 Mei 2016).}


[3] Aaron, C. (2009). Multiple Commitments in the Workplace (An Integrative Approach). New Jersey: Lawrence Erlbaum Associates, Inc.

[4] al, N. e. ( 2011). Fundamental of Human resources management, 4th Edition. USA: McGraw-Hill.

[5] al, S. e. (2010). Organizational behavior, 11th Edition. USA: John Wiley \& Sons, Inc.

[6] Armstrong, M. (2008). Armstrong's Handbook of Reward Management Practice 3th Edition. United Kingdom: Designs and Patents Act.

[7] B, M. J. (2009). Organizational Behavior 1 (Essential Theories of Motivation and Leadership). USA: 2005: M.E. Sharpe, Inc.

[8] Colquitt, LePine, \& Wesson. (2009). Organizational Behavior Improving Performance and Commitment in the Workplace. New York: McGraw-Hill.

[9] David , C. G., \& Geoffrey. (2009). Human Resource Management. USA: Routledge. : A Critical Approach.

[10] Don, H., \& Slocum, J. W. (2011). Principle of Organizational Behavior. South- Western Canada: Eleven Edition.

[11] E, J. C. (2011). Organizational Behavior: Integrating Individuals, Groups, And Organizations 4th edition. New York: Taylor \& Francis.

[12] E, P. J. (2009). Human Resources Management, For Public and Nonprofit Organization. USA: John Wiley \& Sons, Inc.

[13] Finsensia Ansel, M. (2013). Pengaruh Keterlibatan Kerja Dankepuasan Kerja Terhadap Komitmen

Organisasi Polisi di Kepolisian Resor (Polres) Ende (Doctoral dissertation, Magister Sains Psikologi

Program Pascasarjana UKSW).

[14] Jenai, M. (2009). Encyclopedia of Management. USA:: Gale, Cengage Learning.

[15] M A, J. S., \& Scientist Practitioner Approach. (2010). Organizational Psychology. New York: John Wiley \& Sons.

[16] M, G. J., \& Jones, G. R. (2012 ). Understanding and Managing Organizational Behavior. New Jersey: Upper Saddle River.

[17] Mariyanti, E. (2016). PENGARUH KETERLIBATAN KERJA DAN KEPUASAN KERJA TERHADAP KOMITMEN ORGANISASI (STUDI KASUS PADA PERAWAT RUMAH SAKIT SWASTA DI KOTA PADANG). Komputer Teknologi Informasi, 1(1)

[18] Nigel, N. (2008). The Blackwell Encyclopedic Dictionary of Organizational of Organizational Behavior. United Kingdom: Blackwell Publishers Ltd.

[19] P, R. S., \& Coulter, M. (2009). Management. New Jersey: Pearson Prentice Hall.

[20] Robbins, S.P.,\& Coulter,M.(2012).Management.Pearson.

[21] Rider, E. J., \& Hartley, C. L. (2012). Nursing in Today's World: Trends, Issues, and Management, 10th Edition. United States: Walter Kluwer Health Lippicott Williams \& Wilkins.

[22] Robbins, S. P., \& Judge, T. A. (2008). Organizational Behavior. New Jersey: Pearson Prentice Hall.

[23] Robert , K., \& Kinicki, A. (2010). Organizational behavior. New York: McGrawHill/Irwin. .

[24] W, G. R., \& Moorhead, G. (2014). Organizational Behavior Managing People and Organizations. USA: Houghton Mifflin Company.

[25] W, N. J., \& Davis, K. (2009). Organizational Behavior, Human Behavior at Work. New York: McGraw-Hill/Irwin.

[26] Uygur, A., \& Kilic,G. (2008). A Study into Organizational. Commitment and Job Involvement:An Application Towards. Psyche: vol. 1 no. 1, desember 2004. 
[27] Igbaria,M.,Parasuraman,S.,\&Badawy,M.K.(2009).Work Expriences,Job Involvement, and Quality of Work Life among Information System Personnel.Minnesota:Management Information System Research Center, University of Minnesota. MIS Quarterly Vol. 18, No. 2 (Jun., 1994). 